https://helda.helsinki.fi

\title{
Mood in Bulgarian and Macedonian
}

\section{Lindstedt, Jouko}

John Benjamins

2010

Lindstedt, J 2010 , Mood in Bulgarian and Macedonian . in B Rothstein \& R Thieroff (eds), Mood in the languages of Europe. Studies in Language Companion Series, vol. 120 , John Benjamins , Amsterdam/Philadelphia , pp. 409-421.

http://hdl.handle.net/10138/25663

acceptedVersion

Downloaded from Helda, University of Helsinki institutional repository.

This is an electronic reprint of the original article.

This reprint may differ from the original in pagination and typographic detail.

Please cite the original version. 


\title{
Mood in Bulgarian and Macedonian
}

\author{
Jouko Lindstedt \\ (University of Helsinki)
}

\section{Balkan Slavic: Bulgarian and Macedonian}

Bulgarian and Macedonian are two closely related South Slavic languages, the official standard languages of the Republic of Bulgaria and the Republic of Macedonia, respectively. Bulgarian has about 8 million native speakers and Macedonian about 1.5 million. They are used as second (or sometimes first) languages by the ethnic minorities of the two countries; the largest minorities in Bulgaria are the Turks and the Roma, in Macedonia the Albanians. Dialects related to Bulgarian and Macedonian are also spoken in Northern Greece (Greek Macedonia and Thrace) by a Slavic minority whose exact size is not known because of the lack of official statistics. Most of the Slavic speakers there identify themselves as ethnic Macedonians, especially in all the regions west of Thessaloniki, but some as Bulgarians or Pomaks (Muslim Slavs), or they call their native dialect by names such as našta 'ours' (cf. Adamou 2006).

Bulgarian and Macedonian together form the major part of Balkan Slavic, i.e., the Slavic dialect area heavily influenced by contact with the other languages of the Balkan Sprachbund. Macedonian can in fact be considered grammatically the most "Balkanized" of all the Balkan languages (Lindstedt 2000a: 234). Balkan Slavic also includes the so-called Torlak (or Prizren-Timok) dialects of Serbian (see Miloradović \& Greenberg 2001 for a more precise delimitation of the Balkan features in Serbian dialects).

\section{The major finite non-modal verbal categories}

As in other Slavic languages, most Bulgarian and Macedonian verbs are either of the Perfective or Imperfective aspect. The aspect markers are derivational prefixes and suffixes, but the aspect can also be a lexical property of a verb, not marked morphologically. Often an aspectual pair, consisting of two lexically distinct verbs, corresponds to a single lexical verb in languages like English. Thus the English to write may be translated into Bulgarian either with the Imperfective piše or with the Perfective napiše, and into Macedonian either with the Imperfective pišuva or the Perfective piše.

In the finite verb forms, three persons in the singular and three persons in the plural are distinguished. Because there is no infinitive, the citation form of the verb is traditionally the 1st person singular Present in Bulgarian and 3rd person singular Present in Macedonian (with the exception of the verb 'to be' which is even in Macedonian cited in the 1st person singular). However, for better comparability I will use the $3 \mathrm{rd}$ person singular in both languages as it is arguably the most unmarked verb form. 
The major tenses are:

- the Present;

- the Future, marked with a particle (Blg. šte, Mcd. k'e) added to the Present form;

- the Aorist, an inflectional perfective past tense;

- the Imperfect, an inflectional imperfective past tense;

- the 'be' Perfect, a periphrastic form with the auxiliary 'to be' and the Past Active

Participle of the main verb;

- the 'have' Perfect, marginal in Bulgarian but typical of Macedonian: a periphrastic form with the auxiliary 'to have' and the Passive Participle of the main verb (Graves 2000);

- the corresponding Pluperfects.

The Future marker can be combined with other tense markers, which makes for a more complicated tense paradigm in both languages. Some of these more complex tenses will be discussed below in connection with the "conditional domain".

As the semantics of the Perfective/Imperfective opposition is not identical to that of the Aorist/Imperfect opposition, there are not only Perfective Aorists (Blg. napisa, Mcd. piša) and Imperfective Imperfects (Blg. pišeše, Mcd. pišuvaše), but also Perfective Imperfects (Blg. napišeše, Mcd. pišeše) and, at least in Bulgarian, Imperfective Aorists (Blg. pisa - but in Modern Macedonian Imperfective Aorists have become obsolete, see Friedman 1993). For a more detailed study of tense and aspect categories, see Lindstedt (1985) for Bulgarian and Friedman (1977) for Macedonian.

In addition to the unmarked Active voice, there are two periphrastic voices, the Passive and the Reflexive. The Passive is formed with the auxiliary $e$ 'to be' and the Passive Participle of the main verb, e.g. Blg. tărsen e 'is being looked for'. The Reflexive is formed by adding the reflexive object clitic se to the main verb. The Reflexive could better be called the Middle, since $s e$ is a general intransitivizer that marks, besides the strictly reflexive meaning, also various impersonal and reciprocal meanings, and often the Reflexive is more or less synonymous with the Passive proper: Blg. tărsi se 'is being looked for'.

\section{Mood domains in Bulgarian and Macedonian}

The number of moods in grammar books of Bulgarian and Macedonian vary, and so do the paradigms postulated for each mood. There are three major reasons for this. First, not all mood markers in the two languages are bound morphemes, and it is not always easy to distinguish between moods marked analytically (periphrastically) and syntactic constructions. Second, many tense forms, especially those containing the Future marker šte/k'e, also express various modal meanings. Third, both languages have grammaticalized evidentiality (indicating the source of information, see Aikhenvald 2006), but morphologically marked evidentials are classified variously: as moods, as a special subgroup of tenses ("temps seconds" according to Feuillet 1980), or as grams different from both moods and tenses.

The following presentation is based on four modal domains: the imperative domain, the conditional domain, the subjunctive domain, and evidentiality. Each domain is centred around some semantic distinctions that Bulgarian and Macedonian can certainly be said to have 
grammaticalized, but the forms used to mark these oppositions will be described without always taking a firm stand on their status as moods, tenses or even syntactic constructions. As for evidentials, they should really be considered distinct from moods proper, for several reasons: they are not concerned with possibility or necessity, as prototypical moods are; in Bulgarian and Macedonian they are formally closer to tenses than to other grammatical categories; and in both languages, evidentiality crosscuts with mood - there are formal evidential distinctions inside each of the three other modal domains discussed here. But in some other European languages evidentiality is more closely connected with modality (as in the German subjunctive), which is why - for the sake of comparability - evidentiality is nevertheless included in this presentation as the fourth modal domain.

\subsection{The imperative domain}

An inflectional imperative exists only for the second person singular and plural. After verb stems ending in a consonant the Imperative endings are $-i$ (singular) and -ete (plural): sedni, sednete 'sit down!'. In Bulgarian, these endings are always stressed (-i, -éte) irrespective of the stress placement in other forms of the verb. Macedonian follows its usual stress rule: a fixed stress on the antepenultima (the third syllable from the end in words with more than two syllables). Verb stems ending in a vowel have $-j$ (sg.) and -jte (pl.) in both languages: Blg. čakaj, čakajte 'wait!', Mcd. čekaj, čekajte 'wait!'.

In both languages, the Perfective verb dojde 'to come' has a suppletive Imperative ela, elate borrowed from Greek. In Macedonian it is colloquial and "limited to contexts in which the speaker wishes the addressee to come immediately (as opposed to at some later time)" (Friedman 2002: 28). In Bulgarian it is practically the only Imperative of dojde in all uses.

The pronominal clitics for a direct and indirect object are enclitical to the positive Imperative: daj mi go 'give it (go) to me (mi)!' This is peculiar to this mood, since in all other finite verb forms these pronouns are always proclitical in Macedonian, and always proclitical except for the clause-initial position in Bulgarian. The rule of the antepenultimate stress in Macedonian applies to the whole accent group of Imperative + clitics.

The Imperative can be negated with the help of the particle ne as other verb forms: Blg. ne idvaj, Mcd. ne doag'aj 'don't come!'. And as in other verb forms, the pronominal clititics stand between $n e$ and the main verb.

As a rule, the negative Imperative only exists for the verbs of the Imperfective aspect, so the examples given are not only the negated forms of the Imperfective idvaj / doag 'aj 'come!' but functionally also of their Perfective counterparts ela / dojdi. However, Pašov (1989: 146) notes that negated Perfective Imperatives are sometimes possible in Bulgarian when the speaker actually wants the action to be taken and warns of the consequences if it isn't: $T i$ samo ne mu kaží, če šte vidiš posle 'just don't say him and you'll see' (as a warning or threat), where ne kaži 'don't say!' is Perfective. If the speaker actually wants to forbid the saying, only the Imperfective ne kázvaj 'don't say!' is possible.

In both languages the Imperative can also be negated with a special negative auxiliary verb which is itself formally Imperative: Blg. nedej pisa 'don't write! (sg.)', nedejte pisa 'don't write (pl.)'; the Macedonian counterparts are nemoj da pišuvaš (sg.) and nemojte da pišuvate (p1.). In Macedonian the main verb, formally in the Indicative Present, is linked to the negative auxiliary by the particle or complementizer $d a$ (cf. sect. 3.3) as is the usual pattern with auxiliaries in both languages. In Standard Bulgarian the main verb is historically in the Truncated Infinitive, a bare verb stem that has lost the earlier Infinitive ending - $t$ ( pisa < 
pisati). The Truncated Infinitive formally coincides with the endingless second and third person singulars of the Aorist, even in those few verbs where the Aorist and the earlier Infinitive had a different stem. Thus 'don't read! (sg.)' is nedej čéte, though there never existed an Infinitive $*^{*} *_{c}$ eteti, only $*$ česti. Synchronically the Truncated Infinitive may thus be better analysed as a special use of the Imperfective Aorist stem.

The main meaning of the Imperative is jussive (including commands and prohibitions). There is also a minor expressive use of the Imperative second person singular instead of the third person singular or plural of the Indicative Present, as in this Macedonian example (Spasov 1996: 85):

(1) Macedonian
Toj čin- $i$
he do-PRS.SG3 go-IMP.SG2 come-IMP.SG2 and all so
'That's his manner - he goes, he comes, it's always like that.'

In this use, the Imperative typically expresses habitual chains of actions, and there is usually more than one such Imperative in the utterance. The Imperative here represents the mere type of action, as it were, neutralizing all the distinctions of person, tense, aspect, and mood.

Besides the inflectional Imperative in the second persons, in all the persons the jussive meaning can be expressed by the particle $d a$ (cf. sect. 3.3) added to the Indicative Present tense, or with a jussive particle connected with the Indicative Present either directly or with the help of $d a$. The most usual such particles are neka, which has cognates in other Slavic languages, and (Blg.) xajde / (Mcd.) ajde, which is a Pan-Balkan lexical item, e.g. Blg. xajde da otidem na kino 'let's go to the cinema'. In these constructions the clitic placement and the use of the Perfective and Imperfective aspect is the same as in the Indicative.

\subsection{The conditional domain}

"Conditional" is the usual name in the grammars of many languages for a mood used in counterfactual (contrafactive, irreal) sentences - which may or may not contain a condition clause. For expressing counterfactuality, there are two series of verb forms in Bulgarian and Macedonian - one inherited from Proto-Slavic, the other shared with neighbouring Balkan languages. In Bulgarian, the Slavic conditional has a special auxiliary $b i$ - with Aorist personal endings, combined with the Past Active Participle of the main verb. In Macedonian, the auxiliary has become an uninflected particle, so that there is no person marker in this periphrastic verb form:

Bulgarian
az bix došăl / došla
ti bi došăl / došla
toj bi došăl
tja bi došla
to bi došlo
nie bixme došli
vie bixte došli
te bixa došli

Macedonian

jas bi došol / došla 'I would come (M/F)'

ti bi došol / došla you (SG) would come (M/F)'

toj bi došol

taa bi došla

toa bi došlo

nie bi došle

vie bi došle

tie bi došle 'he would come'

'she would come'

'it (N) would come'

'we would come'

'you (PL) would come'

'they would come' 
The other conditional in both languages is the so-called "Balkan-type conditional" (term introduced by Gołąb 1964) which is in fact similar to the counterfactual expressions in several other European languages. It combines the markers of the Future and the Imperfect. In the protasis (if-clause) of a counterfactual conditional sentence, the Imperfect alone without the Future marker is used, though the time reference is not necessarily past:

(2) Bulgarian

Št-ja-x dadojd-a ako namer-e-x vreme.

FUT-IMPF-SG1 $d a$ come-PRS.SG1 if find-IMPF-SG1 time

'I would come if I found time'; 'I would have come if I had found time'

(3) Macedonian

K'e dojd-e-v ako najd-e-v vreme.

FUT come-IMPF-SG1 if find-IMPF-SG1 time

'idem'

As these examples show, in the apodosis, Macedonian combines the uninflected Future marker $k$ ' $e$ with the Imperfect of the main verb, whereas in Bulgarian the Future marker šte itself is inflected in the Imperfect and the appropriate person, and the main verb in the Present tense is linked to it by $d a$, as is usually the case after auxiliaries. Macedonian conforms here with several other Balkan languages (Albanian, Greek, Southern Aromanian), whereas Bulgarian is only similar to some Aromanian and Daco-Romanian dialects (Asenova 2002: 220-240; Gołąb 1964: 178). There are even Bulgarian dialects where the structural model is similar to Macedonian: šte dojdex.

In the Bulgarian grammatical tradition, only the "Slavic" bi series is called the "Conditional Mood". The "Balkan" type, as in the apodosis of (2), is classified as a tense (futurum praeteriti, the Past Future) that also happens to have modal uses. In actual fact, the two types are nearly synonymous in a counterfactual apodosis, and in a counterfactual protasis the Balkan type, i.e., the mere Imperfect, is predominantly used irrespective of which of the two forms is in the apodosis. In her monograph on the Bulgarian Conditional, Panteleeva (1998: 93) considers the two types to be functionally equivalent in counterfactual conditional sentences. Maslov (1981: 281) finds a slight difference between the two in (4) and (5):

(4) Bulgarian
Ako im-a-x
pari, $\quad \check{s} t-j a-x$
da $t i \quad d a-m$
ej sega.
if have-IMPF-SG1 money FUT-IMPF-SG1 $d a$ you.DAT give-PRS.SG1 just now
'If I had money, I'd give you some immediately.'

(5) Bulgarian
Ako im-a-x
pari, $\quad$ bi-x
ti da-l
ej sega.
if have-IMPF-SG1 money COND-SG1 you.DAT give-PCPL.M just now
'If I had money, I'd (like to) give you some immediately.'

Similarly, in the grammar of the Bulgarian Academy of Sciences (Stojanov (ed.) 1983: 371) the Balkan type is said to express the action as dependent on some external condition only, whereas the $b i$ type suggests that it is also dependent on the decision of the agent.

There are certainly other types of contexts where the Bulgarian Past Future is closer to a real tense. On the other hand, there are modal contexts where the Bulgarian bi conditional cannot be replaced with the Past Future, notably as a courtesy marker in expressions such as bix vi pomolil 'I'd like to ask you' or bixte li mi pomognali? 'could you please help me?'.

Another type of modal verbal form is the so-called "Simple Conditional" found in Bulgarian dialects and also used in the 19th-century standard language. "Simple" here means "not periphrastic": the marker is $-v-$, originally a suffix for forming Imperfective verbs, but in this use added even to verbs which are already Imperfective, such as in jade 'eats' -jad-v-a 
'would like to eat, can eat'; pravi 'does' - prav-v-a 'would like to do, can do'. As noted by Pašov (1989: 148), the meaning of such forms is not really conditional, but they express inclination or the possibility of doing something. In the modern standard language they are only archaisms.

As for Macedonian, the use of the bi series is even more limited by the Balkan conditional than in Bulgarian. In dialects, it is mainly used in optative sentences, such as in blessings and curses, its use in conditional sentences being rarer (Koneski 1990: 203-205). It seems that its more frequent use in the standard language is at least partly due to Serbian and other Slavic influences (ibid.; Minova-G'urkova 1998: 118; Friedman 2002: 32; cf. also Hacking 2001). In the Macedonian grammatical tradition it is not called "conditional mood" as in Bulgarian, but "potential mood" (možen način).

The name "conditional" in Macedonian is used not only for the modal function of the Past Future (the Balkan conditional), but also for the modal function of the ordinary Future, the difference being that between unreal and possible situations (Friedman 2002: 32-33, Usikova 2000: 140-141). This is partly a difference between the grammatical traditions of the two languages, but it does seem to be the case that different modal uses of the Future marker $k$ ' $e$ are more widespread in the Macedonian standard language than in the Bulgarian standard, and the use of the $b i$ series is more limited (Topolinjska 1996: 63-82 is one of the very few contrastive studies of Bulgarian and Macedonian on this subject). The Past Future of Macedonian is also frequently used to express habitual actions in the past, which the Bulgarian Past Future normally cannot express (op.cit., p. 69, 79).

\subsection{The subjunctive domain}

"Subjunctive is the term given to special verb forms or markers that obligatorily occur in certain types of subordinate clauses" is the definition given by Bybee \& al. (1994: 212-213). They point out that often the use of the subjunctive is dictated by the surrounding context, but in certain types of clauses there may be an opposition of meaning between the subjunctive and the indicative.

As in other Balkan languages, the main verb after an auxiliary is in Bulgarian and Macedonian not in the infinitive (which does not exist), but in the appropriate person of the Present tense, linked with the auxiliary by a particle / complementizer. Thus, 'I want to read' is in Bulgarian iskam da četa, in Macedonian sakam da čitam - the particle is da, and both the auxiliary and the main verb are in the first person singular of the Present. The $d a$ construction has several other uses as well, and some grammars of both languages classify it as an analytically marked Subjunctive mood. This view is held especially by Russian linguists, as in Maslov's (1981) grammar of Bulgarian and Usikova's (2000) grammar of Macedonian. (Actually they use the Russian term kon''junktiv, but this is a mere difference of name.) The approach has its model in the grammars of Modern Greek, where the functionally similar $n a$ constructions (and sometimes constructions with other markers as well) are classified as subjunctives (cf. Mackridge 1985: 274-306).

The $d a$ construction does have several mood-like uses. In jussive sentences it, alone or with jussive particles, can be used instead of the Imperative. It also compensates for the missing person and aspect forms of the Imperative, as in Bulgarian da vărvim 'let's go' (there is no first person plural of the inflectional Imperative), da ne ostaneš tam 'don't stay there' (with a Perfective verb that could not be used in a negated Imperative). The $d a$ construction can also appear in a relative clause: 
(6) Bulgarian

Izbran e konsultant-ăt, koj-to da predlož- $i \quad$ rešenie.

chosen is consultant-DEF who.M-REL $d a$ propose-PRS.SG3 solution

'The consultant who should propose a solution has been chosen.'

On the other hand, $d a$ is often the sole marker of the subordinate clause, though it remains proclitical to the verb:

(7) Bulgarian

Isk-am tja dadojd-e.

want-PRS.SG1 she $d a$ come-PRS.SG3

'I want her to come.'

Notice that the subject pronoun tja is used here, not its object form ja-this shows that the pronoun is the subject of the subordinate clause, not the object of the matrix clause. In complement clauses the modal distinction is not so much between a verb with $d a$ and a verb without $d a$, but rather between the complementizer če (Blg.) / deka (Mcd.) 'that' marking a factive reading and $d a$ marking a non-factive reading:

(8) Macedonian

Zaborav-i-v deka sed-am vo kancelarija.

forget-AOR-SG1 that sit-PRS.SG1 in office

'I forgot that I was sitting in an office.'

(9) Macedonian

Prozorec-ot zaborav-i-v da go zatvor-am.

window-DEF forget-AOR-SG1 $d a$ it.OBJ close-PRS.SG1

'I forgot to close the window.'

Although there is nothing inherently impossible in the idea of a mood marked analytically, I still think $d a$ is best analysed as a complementizer, not as a subjunctive marker. This is because it is often the sole marker of a subordinate clause, being in complementary distribution with all other complementizers and with most markers of subordination in general (the notable exception being the relative pronouns, as in (6) above). At most, it would be possible to speak about "subjunctive clauses", as Mackridge (1985: 274) does for Modern Greek, as a special subgroup of clauses with certain limitations in the use of tenses, but such subjunctives would not be a mood category of the verb itself.

\subsection{Evidentiality}

As in neighbouring Turkish, Albanian, and Aromanian, both Bulgarian and Macedonian have grammaticalized evidential distinctions (Friedman 1986, Lindstedt 1994). Basically this means that a special verbal form must be used when speaking about a situation, especially a past one, that the speaker has not herself witnessed, though the semantic details vary from one language to another. Thus the Macedonian and Bulgarian Indicative Aorist and Imperfect cannot be used in sentences like (10), where a special non-witnessed form of the verb, based on the Past Active Participle, is used instead:

(10) Bulgarian

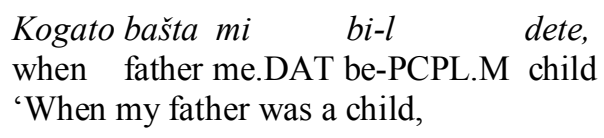


The use of the Indicative Imperfect (učilištata bjaxa po-dobri ot segašnite 'schools were better than nowadays') would imply that the speaker was alive at that time.

The basic opposition is between witnessed and non-witnessed situations. The two main types of non-witnessed situations are those that have been reported by other persons, as in (10), and those inferred by the speaker on the basis of their results, as in (11):

(11) Macedonian

Kradec-ot vlego-l vo kuk'a-ta preku ovoj prozorec.

thief-DEF enter-PCPL.M in house-DEF through this.M window

'The thief entered the house through this window.'

Here the speaker sees, say, footprints and a broken window, and infers what must have happened. The use of an Indicative Aorist vleze 'entered' would imply that the speaker actually saw the thief enter the house.

The non-witnessed forms are usually called "reported" (Blg. preizkazni, Mcd. prekažani) in the grammatical traditions of the two languages, but actually they are used both for reported and inferred events, hence terms like "non-witnessed" or "indirect" are to be preferred. Other terms sometimes used are "quotative", which is misleading because the non-witnessed forms do not quote but report other persons' speech, and "narrative", which is likewise misleading since both witnessed and non-witnessed forms can be used in narrative discourses.

The non-witnessed or indirect evidentials can also be used to express that the speaker, although now witnessing the situation in person, finds it unexpected. This is the so-called mirative (or admirative) function, illustrated by the first verb in this example (from Stojanov 1983: 361):

$$
\begin{aligned}
& \text { Bulgarian } \\
& T i \quad \text { si zna-e-l } \\
& \text { you be.SG2 know-IMPF-PCPL.M interesting-PL something-PL but be.silent-PRS.SG2 } \\
& \text { 'You know interesting things, why do you keep silent?" }
\end{aligned}
$$

The paradigm of the indirect (non-witnessed) evidentials is based upon the old Perfect Tense, consisting of the auxiliary 'to be' and the Past Active Participle of the main verb:

$\begin{array}{lll}\text { Bulgarian } & \text { Macedonian } & \\ \text { az săm došăl / došla } & \text { jas sum došol / došla } & \text { 'I came (M/F)' } \\ \text { ti si došăl / došla } & \text { ti si došol / došla } & \text { 'you (SG) came (M/F)' } \\ \text { toj (e) došăl } & \text { toj došol } & \text { 'he came' } \\ \text { tja (e) došla } & \text { taa došla } & \text { 'she came' } \\ \text { to (e) došlo } & \text { toa došlo } & \text { 'it (N) came' } \\ \text { nie sme došli } & \text { nie sme došle } & \text { 'we came' } \\ \text { vie ste došli } & \text { vie ste došle } & \text { 'you (PL) came' } \\ \text { te (sa) došli } & \text { tie došle } & \text { 'they came' }\end{array}$

Macedonian always omits the auxiliary in the third person, and Bulgarian drops it optionally. In normative Bulgarian grammars the third-person distinction between the types toj e došăl and toj došăl is often described as an opposition between the Perfect proper (which should retain the auxiliary) and the Reported Aorist (which should omit it), or as an opposition between inferred and reported evidential use. However, it has now been shown that the auxiliary drop does not strictly depend on the evidential semantics but on discourse factors 
(Roth 1979; Lindstedt 1994; Fielder 2001; Friedman 2001; Alexander 2001). If the speaker has heard of somebody's arrival but has not witnessed it, the auxiliary is not usually dropped when reporting it:

(13) Bulgarian

Toj e došă-l.

he be.SG3 come-PCPL.M

'He has come.'

However, if this is developed towards a mini-narrative, the auxiliary $e$ can be dropped:

(14) Bulgarian

Toj došă-l, pi-l edn-o kafe $i$ pak si trăgna-l.

he come-PCPL.M drink-PCPL.M one-N coffee and again REFL.DAT depart-PCPL.M

'He came, drank a coffee and went his way (I've been told).'

It is therefore not the case that Bulgarian indirect evidentials always omit the Perfect auxiliary in the third persons singular and plural, although most grammars and textbooks continue to repeat this. It is, however, true that if the auxiliary is omitted, the form is better classified as an indirect past tense and not as a Perfect. In other words, the auxiliary drop is a sufficient but not necessary condition for the non-witnessed reading.

Both languages have developed several indirect tenses on the same structural model. There is, for instance, a common form for the Indirect Future and Indirect Past Future. Bulgarian does this by inflecting the Future marker in the Perfect:

(15) Bulgarian

Št-ja-l săm dana-prav-ja tri pătešestvi-ja do Orient-a.

FUT-IMPF-PCPL.M be.PRS.SG1 $d a$ PFV-do-PRS.SG1 three trip-PL to Orient-DEF

'Allegedly I am/was going to make three trips to the Orient.'

In Macedonian, this indirect tense is formed by attaching the uninflected Future marker to the indirect Imperfect form ( $k$ 'e sum napravel).

Given that the 'be' Perfect is basically homonymous with the Indirect Aorist in Bulgarian, and with the Indirect Aorist and Imperfect in Macedonian, it would be tempting to omit it altogether as a tense from the descriptions of these languages. However, the Perfect still has many uses in Bulgarian in which the event is clearly witnessed, and in such cases its syntactic behaviour is partly different from the Indirect Aorist (Lindstedt 1994: 48-49), so it seems that the two forms still have to be kept distinct. As for Macedonian, the situation is more complicated because another perfect tense exists which uses the auxiliary ima 'to have' (Graves 2000, Lindstedt 2000b). The 'have' perfect is gradually taking over the traditional functions of the 'be' perfect to such an extent that only the evidential functions remain for the latter (Minova-G'urkova 1998: 117).

Some modal forms of the verbs can also have their evidentially indirect counterparts. For morphological reasons this is impossible for the inflected (synthetic) Imperative and the $b i$ Conditional/Potential, but the Balkan type conditional freely accepts Indirect Imperfects and Indirect Past Futures:

(16) Bulgarian

Toj njama-l ništo za pisane,

he not.have-PCPL.M nothing for writing

'(He said that) he had nothing with which to write,

no ako im-a-l, $\quad \check{s} t$-ja-l da na-piš-e ...

but if have-IMPF-PCPL.M FUT-IMPF-PCPL.M $d a$ PFV-write-PRS.SG3

but (he claimed that) if he had (had), he would write / would have written...' 
When $d a$ marks a complement clause, the verb after it does not normally appear in an indirect form. Similarly, when it links a modal auxiliary to the main verb, only the auxiliary accepts indirect endings. But in main clauses $d a$ in its jussive function can sometimes combine with an indirect evidential (Maslov 1981: 288):

(17) Bulgarian

$$
\begin{aligned}
& \text { Kakvo da prav-e-l } \quad v \text { Plovdiv? } \\
& \text { what da do-IMPF-PCPL.M in Plovdiv? } \\
& \text { 'What should he do in Plovdiv?' }
\end{aligned}
$$

In this example, the speaker has heard somebody ask Kakvo da pravja $v$ Plovdiv? 'What should I do in Plovdiv?' (a direct evidential) and echoes the question in an indirect evidential; the implicature is "it's odd for him to ask such a question". Examples like (16) and (17) show that evidentiality in Bulgarian and Macedonian is best regarded as a category distinct from mood proper.

\section{Conclusion}

The system of moods in Bulgarian and Macedonian can be described in different ways, depending on what status is assigned to various analytical constructions and whether evidential distinctions, indicating the source of information, are classified as modal or not. The sole synthetic (inflectional) non-indicative mood is the Imperative of the second person singular and plural. There are several analytic jussive constructions complementing the synthetic Imperative. For various counterfactual and potential meanings, Bulgarian and Macedonian make use both of a special periphrastic paradigm (which is more marginal in Macedonian) and various tense forms that have acquired modal functions. The preverbal particle $d a$ is sometimes considered to be a Subjunctive marker, but there seem to be stronger reasons to classify it as a complementizer (with a modal meaning, to be sure). Finally, the grammatical marking of evidentiality, which is a central category in the verb system of both languages, cross-cuts the modal distinctions, which is one of the reasons for not regarding it as a mood category in the strict sense.

\section{Abbreviations not found in the Leipzig Glossing Rules:}

AOR aorist (inflectional perfective past tense), IMPF imperfect (inflectional imperfective past tense), PFV (perfective aspect), PCPL (participle)

\section{References:}

Adamou, E. 2006. Le nashta. Description d'un parler slave de Grèce en voie de disparition [Languages of the World / Materials 456]. München: Lincom Europa.

Aikhenvald, A. Y. 2006. Evidentiality in grammar. In Encyclopedia of language and linguistics, 2nd ed., Vol. 4, K. Brown (ed.), 320-325. Amsterdam: Elsevier Science.

Alexander, R. 2001. Bridging the descriptive chasm: The Bulgarian "Generalized Past". In Friedman and Dyer (eds.) 2001, 13-42.

Asenova, P. 2002. Balkansko ezikoznanie. Osnovni problemi na balkanskija ezikov săjuz. [2nd ed.] Veliko Tărnovo: Faber.

Bybee, J. and Perkins, R. and Pagliuca, W. 1994. The Evolution of Grammar: Tense, Aspect, and Modality in the Languages of the World. Chicago and London: University of Chicago Press. 
Dahl, Ö. (ed.). 2000. Tense and Aspect in the Languages of Europe [Empirical Approaches to Language Typology 20-6]. Berlin and New York: Mouton de Gruyter.

Feuillet, J. 1980. Le système des temps seconds en bulgare moderne. Die Welt der Slaven 25, $22-38$.

Fielder, G. E. 2001. Questioning the dominant paradigm: An alternative view of the grammaticalization of the Bulgarian evidential. In Friedman and Dyer (eds.) 2001, 171-201.

Friedman, V. A. 1977. The Grammatical Categories of the Macedonian Indicative. Columbus, OH: Slavica.

Friedman, V. A. 1986. Evidentiality in the Balkans: Bulgarian, Macedonian, and Albanian. In Evidentiality: The Linguistic Coding of Epistemology [Advances in Discourse Processes 20], W. Chafe and J. Nichols (eds), 168-187. Norwood, New Jersey: Ablex.

Friedman, V. A. 1993. The loss of the imperfective aorists in Macedonian: Structural significance and Balkan context. In American Contributions to the Eleventh International Congress of Slavists, R. A. Maguire and A. Timberlake (eds.), 285-302. Columbus, OH: Slavica.

Friedman, V. A. 2001. Hunting the elusive evidential: The third-person auxiliary as a boojum in Bulgarian. In Friedman and Dyer (eds.) 2001, 203-230.

Friedman, V. A. 2002. Macedonian [Languages of the World / Materials 117.] München: Lincom Europa.

Friedman, V. A. and Dyer, D. L. (eds.). 2001. Of All the Slavs My Favorites. In Honor of Howard I. Aronson on the Occasion of His 66th Birthday [Indiana Slavic Studies, 12]. S.l.: Indiana University.

Gołąb, Z. 1964. Conditionalis typu batkańskiego w językach południosłowiańskich, ze szczególnym uwzględnieniem macedońskiego [Polska Akademia Nauk, Oddział w Krakowie, Prace Komisji Językoznawstwa 2.] Wrocław, Kraków and Warszawa: Polska Akademia Nauk.

Graves, N. 2000. Macedonian - a language with three perfects? In Ö. Dahl (ed.) 2000, 479494.

Hacking, J. 2001. Attitudes to Macedonian conditional formation: The use of dokolku and bi. In Friedman and Dyer (eds.) 2001, 231-242.

Koneski, K. 1990. Glagolskite konstrukcii so k'e vo makedonskiot jazik. Skopje: Institut za makedonski jazik "Krste Misirkov".

Lindstedt, J. 1985. On the Semantics of Tense and Aspect in Bulgarian [Slavica Helsingiensia 4]. Helsinki: University of Helsinki, Department of Slavonic Languages.

Lindstedt, J. 1994. On the development of the South Slavonic Perfect. EUROTYP Working Papers VI,5: Three Papers on the Perfect, 32-53. Reprinted in Lindstedt, J. Kontakto kun Balkanio [Slavica Helsingiensia, Supplementum III], 215-236. Helsinki 2005: Department of Slavonic and Baltic Languages and Literatures. Also available at http://www.helsinki.fi/ jslindst/kontakto_kun balkanio.pdf

Lindstedt, J. 2000a. Linguistic Balkanization: Contact-induced change by mutual reinforcement. In Languages in Contact [Studies in Slavic and General Linguistics 28], D. Gilbers and J. Nerbonne and J. Schaeken (eds.), 231-246. Amsterdam and Atlanta, GA: Rodopi.

Lindstedt, J. 2000b. The perfect - aspectual, temporal and evidential. In Ö. Dahl (ed.) 2000, $265-283$.

Lindstedt, J. 2002. Is there a Balkan verb system? Balkanistica 15, 305-318.

Mackridge, P. 1985. The Modern Greek language. Oxford: Clarendon Press.

Maslov, Ju. S. 1981. Grammatika bolgarskogo jazyka. Moskva: Vysšaja škola. 
Miloradović, S. and Greenberg, R. 2001. The transition from South Slavic to Balkan Slavic: Key morphological features in Serbian transitional dialects. In Friedman \& Dyer (eds.) 2001, 311-322.

Minova-G'urkova. L. 1998. Morfologija. In Makedonski jazik [Najnowsze dzieje języków słowiańskich], L. Minova-G’urkova (ed.), 108-119. Opole: Uniwersytet Opolski, Instytut Filologii Polskiej.

Panteleeva, X. 1998. Kondicionalăt v săvremennija bălgarski knižoven ezik. Sofija: Prof. Marin Drinov.

Pašov, P. 1989. Praktičeska bălgarska gramatika. Sofija: Narodna prosveta.

Roth, J. 1979. Die indirekten Erlebnisformen im Bulgarischen: Eine Untersuchung zu ihrem Gebrauch in der Umgangssprache [Slavistiche Beiträge 130]. München: Otto Sagner.

Spasov, Lj. 1996. Od problematikata na imperativot vo makedonskiot jazik (za t.n. "raskazen / raskažuvački imperativ"). In Studia linguistica polono-meridianoslavica 8, B. Vidoeski and Z. Topolinjska and A. Peco (eds.), 81-88. Skopje: Makedonska akademija na naukite i umetnostite, Oddelenie za lingvistika i literaturna nauka.

Stojanov, S. (ed.) 1983. Gramatika na săvremennija bălgarski knižoven ezik, II: Morfologija. Sofija: Izdatelstvo na Bălgarskata akademija na naukite.

Topolinjska, Z. 1996. Studii od makedonsko-bugarskata jazična konfrontacija. Skopje: Makedonska akademija na naukite i umetnostite.

Usikova, R. P. 2000. Makedonskij jazyk. [2nd ed.] Skopje: Filološki fakultet "Blaže Koneski”". 